\title{
China Rising and Its Changing Policy on UN Peacekeeping
}

\author{
Yin He
}

The ${ }^{1,2}$ past four decades we have witnessed China's increasingly active participation in United Nations Peacekeeping Operations (PKOs). The existing literature on this issue has an obvious feature: many writers have focused on policy analysis or review (Stahle 2008; Gill and Huang 2009; International Crisis Group 2009; Lanteigne 2014). According to those analysts, China's active participation in PKOs is largely driven by a long list of pragmatic needs or interests ranging from belief in multilateralism and image building to more traditional concerns such as isolating separatist forces in Taiwan and securing its overseas investments (Gill and Huang 2009). Hence, it has been very difficult for different writers to agree on the core reason behind China's changing attitude towards UN peacekeeping. Some writers have applied theoretical analysis to their

\footnotetext{
${ }^{1}$ The views expressed in this chapter are the author's personal opinions. They do not represent the views of the China Peacekeeping Police Training Center or the Chinese Ministry of Public Security.

${ }^{2}$ This research was supported by the China National Social Sciences Fund project "China's Strategy on Participation in UN Peacekeeping Operations" (16ZDA094).
}

Y. He $(\bowtie)$

China Peacekeeping Police Training Center, Langfang, China

(C) The Author(s) 2019

C. de Coning and M. Peter (eds.), United Nations

Peace Operations in a Changing Global Order, https://doi.org/10.1007/978-3-319-99106-1_13 
research in China's peacekeeping behaviour (Sicurelli 2010), but they have failed to find the most important variable driving China's changing peacekeeping behaviour. In the 1970s, China opposed PKOs; today, it is a major supporter of UN peacekeeping. Is there any fundamental variable shaping this significant change? If there is, what is it, and how has it affected China's attitude towards the UN peacekeeping regime? This chapter explores the cause and effect of China's changing policy on UN peacekeeping, and argues that changes in China's national identity have led to changes in the country's foreign policy, including that on UN peacekeeping.

The first section of this chapter presents an analytical framework, and proposes the hypothesis that China's national identity is the most important factor shaping its behaviour within the UN peacekeeping regime. The second section discusses how China's international identities have affected its policy on UN peacekeeping during the period from 1971 to 2000. The third section analyses China's national identity and policy on UN peacekeeping in the twenty-first century. The last section concludes by raising questions for further research.

\section{Analytical Framework}

Many researchers believe that China's current policy of increasingly active participation in UN peacekeeping is largely driven by a long list of pragmatic needs or interests (Lynch 2014; Lanteigne 2014; Fung 2016). According to them, China's policy on peacekeeping is the result of a reactive response to those pragmatic needs or interests.

One cannot deny that national interests, especially the immediate ones, can affect a state's policy on international affairs. However, one will also find it hard to believe that a realism-oriented policy analysis can show the full picture of China as an active peacekeeper, especially given China's rise over the past four decades. In fact, many arguments based on policy analysis are easy to falsify. For example, some point to South Sudan and argue that China's participation in UN peacekeeping is driven by its increasing need for natural resources, such as oil (Lynch 2014). However, the deployment of substantial numbers of peacekeeping troops to places like Darfur, Lebanon, and Haiti-which lack significant stocks of natural resources-surely limits the strength of this argument. For another example, some analysts argue that Beijing's One China policy is the most important factor affecting the country's peacekeeping 
behaviour (International Crisis Group 2009). This might have been true in the 1980s and 1990s. However, as shown in its continuous support for the UN peacekeeping efforts in Haiti, a poverty-stricken Caribbean state which has long adopted a pro-Taiwan policy, geopolitical factors are not the most significant variable affecting present-day China's peacekeeping behaviour.

Any state's interests in international affairs are subject to change over time. This has been the case with China's interests in UN peacekeeping. In the 1970s, China stayed away from UN peacekeeping due to its normative stance on state sovereignty and non-intervention. From the 1980s to the 1990s, China's gradual adjustment of its attitude towards UN peacekeeping was mainly due to its need for a favourable international environment that could benefit its own economic development-oriented reform and opening up strategy. In the new century, China's increasingly active participation in UN peacekeeping serves three major interests: being a responsive power, strengthening the UN, and sharing common concerns for peace and security ( $\mathrm{He} 2007)$.

To explore the fundamental reason behind China's changing policy on UN peacekeeping, one needs to look beyond China's pragmatic interests and answer the following question: Why has China shown different interests in UN peacekeeping affairs over the past four decades? Constructivism provides an insightful perspective for answering the question. According to this theoretical perspective, identity defines interests (Wendt 1999; Finnemore 1996). Applying this idea to the case of China's engagement in UN peacekeeping, the changing policies in this area derive from key shifts in China's national identity. Moreover, as constructivism also holds that interests define behaviour, there are causal relations between identity and behaviour. This chapter analyses the link between China's evolving national identity and its changing policy on UN peacekeeping in terms of causal relations.

However, in this chapter, the concept of "identity" is based on, but not limited to, the way in which it appears within the constructivist literature. Rather than the idea of a shared culture that is largely unaffected by material factors, here identity is conceptualised as being affected by both ideational and material factors (Kratochwill 1989; Ruggie 1998). Although the chapter does not take a purely theoretical stance, it adopts an eclectic analytical framework which draws theoretical support from mainstream international relations meta-theoretical approaches, including realism, institutionalism, and constructivism. To be more specific, 
China's national identity is mainly constructed by three factors: the country's increasing comprehensive national strength, its increasingly active participation in the international institutions, and its increasing socialisation within the international community (Johnston 2008).

\section{China’s Changing National Identity and Policies on UN Peacekeeping Before the Twenty-First Century}

Significant political, military, and social changes tend to generate shifts in a state's national identity (Qin 2005). During the period from 1971 to the end of the twentieth century, China's national identity has undergone two distinctive phases: from a semi-revolutionist state largely staying out of the international community dominated by the Western powers in 1970 s, to an integrated member of the international community in 1980 s and 1990s. Each of these phases had led China to develop different policies on UN peacekeeping. These two identities were later on replaced by a third and current one; that of a rising power, which also brought with it stronger Chinese engagement with UN peacekeeping operations.

\section{A Semi-revolutionist State in 1970s}

In the 1970s, China was to some degree a revolutionary state, or a semi-revolutionary state, in that it kept a sceptical eye on the existing international community dominated by the Western powers. Despite having returned to the UN in 1971 and gradually improved relations with the Western powers, especially after Richard Nixon's historic visit in 1972, China's international outlook had not changed significantly. It continued to regard itself as a victim of the imperialist behaviour of the two superpowers - the United States (along with other Western capitalist powers) and the Soviet Union-as it did in the 1960s, and identified itself with the Third World (Choedon 2005). During this period, revolution and struggle were still the banners of China's diplomacy. China wished to fulfil its international moral responsibility towards other Third World countries by strictly adhering to the Westphalian norms of state sovereignty and non-intervention. As a state which to a great extent remained outside the international community dominated by the West, China did not have much interest in accepting the rules and norms of the international system. As a result, it condemned and opposed the creation of new PKOs and the continuation of the existing missions, refused 
to share the burden of the peacekeeping budget or contribute personnel to ongoing operations, and abstained from UNSC voting (He 2007). The People's Liberation Army (PLA) was preoccupied with its traditional task of safeguarding China's territorial integrity and had no interest in international operations like peacekeeping. As a result, throughout in the 1970s China remained opposed to UN peacekeeping.

\section{An Integrated Member in 1980s and 1990s}

In the 1980s and 1990s, as China sought to become an integrated member of the international community, it began to selectively embrace the UN peacekeeping regime. Beijing's adoption of economic reform and opening up policy, starting at the end of the 1970s, shifted its focus from domestic as well as international revolution to development, especially economic development. After re-establishing diplomatic relations with the major Western states, especially the United States, China found its international security environment greatly improved (Kim 1987), which enabled it to allocate limited resources towards development-oriented reform and to its opening-up strategy. This in turn improved China's international status and self-confidence as a participant in international affairs. During the 12th National Congress of the Communist Party of China (CPC) held in 1982, an "independent foreign policy of peace" (duli zizhu de heping waijiao zhengce) was formulated, marking China's new willingness to play down its ideological disagreement with the West and its determination to seek peaceful coexistence (He 2007). China's adoption of the independent foreign policy of peace reflected its pragmatic strategy of integrating into the international community. Despite changes in both the international and domestic environment, Beijing largely stuck to this strategy throughout 1980s and 1990s. To this end, China needed to make good use of its limited domestic and international resources. As a veto-wielding permanent member in the UNSC, China found that its policy on UN peacekeeping, if well designed, could generate precious diplomatic capital, especially to break the isolation imposed by the Western states after 1989. As a result, Beijing gradually became engaged in UN peacekeeping.

This shift entailed several measures. First, China adjusted its attitude towards UN peacekeeping by providing financial support for PKOs and by participating in UNSC voting. In 1981, China voted in the UNSC for the first time, in favour of Resolution 495, which extended the ongoing UN Peacekeeping Force in Cyprus (UNFICYP). In 1982, China began 
to pay its dues for peacekeeping. Then, it began to show interest in participating in UN peacekeeping. In November 1988, China joined the UN Special Peacekeeping Committee. Five months later, in an unprecedented move, China's ambassador to the UN, Yu Mengjia, called on the international community to give powerful support to UN peacekeeping. Finally, in 1990, China became a peacekeeper by deploying five military observers to the UN Truce Supervision Organization (UNTSO) in the Middle East.

China's policy on UN peacekeeping in 1980s and 1990s largely reflected a balance between its traditional normative position and pragmatic concerns for its national interests, in particular those regarding its strategy of becoming an integrated member of the international community. During this period, especially in the 1990s, China had shown a certain degree of flexibility in its policy on UN Peacekeeping, in particular on the principle of use of force. Thirty-six PKOs were established between 1988 and 1998. China voted in favour of all operations that carried out traditional peacekeeping tasks as well as the continuation of all ongoing traditional PKOs that were established during the Cold War era. At the same time, it had not vetoed any PKOs mandated under Chapter VII of the UN Charter. Most notably, after Iraq invaded Kuwait, in November 1990 China chose abstention rather than a veto during the voting on UNSC Resolution 678, which authorised Member States to use all necessary means to restore international peace and security in Kuwait.

Being eager to get integrated into the international community, China would often react to deeds of other countries that challenged its membership. In 1997, China vetoed a UNSC draft resolution to deploy military observers to verify the implementation of ceasefire agreements in Guatemala, which had been active in pushing for Taiwan's membership in the UN. In 1999, Macedonia shifted its recognition from Beijing to Taipei 17 days before the UNSC intended to deliberate upon the extension of the UN Preventive Deployment Force (UNPREDEP). Beijing was enraged and vetoed the UNSC draft resolution.

\section{China's National Identity and Policy on UN Peacekeeping in the Twenty-First Century}

The third and current Chinese identity is one of a rising power, which is coupled with a stronger engagement in UN peacekeeping operations. China, indeed, is a rising power in the twenty-first century (Ikenberry 2008). It needs a foreign policy fitting into its strategy for peaceful rise. This section 
examines China's new national identity and policy on UN peacekeeping in the new century. Key questions to be answered include: how has the new national identity come into been?, and how has it affected China's policy on UN peacekeeping?

\section{A Rising Power in the Twenty-First Century}

China's strategy of being an integrated member of the international community in 1980s and 1990s proved a success. Continuous adoption of the development-oriented policy and increasing socialisation into the international community have contributed to rapid growth of national strength. Entering the twenty-first century, China's further integration into the global economy, marked by its participation in the World Trade Organization, among other things, secured the prospect of continuous high-speed economic growth. In the first decade of the twenty-first century, China's national strength had reached a new height. As is shown in Chart 13.1, according to statistics provided by the United Nations Statistics Division (2016), China's Gross Domestic Product (GDP) surpassed those of Germany, France, and the United Kingdom in around 2005. In 2010 it overtook Japan to become the second largest economy.

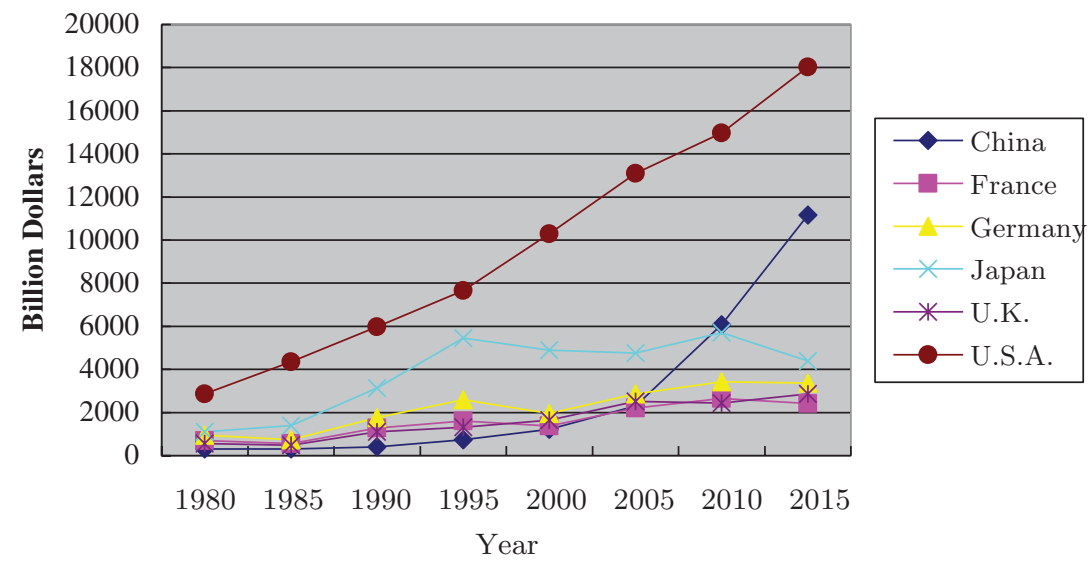

Chart 13.1 China and Major Western Powers' GDP (Source Author's own calculation based on data from United Nations Statistics Division 2016) 
Enhanced national strength encourages China to rethink its identity in the international arena. In 1999, after China successfully tided over the Asian Financial Crisis, then Chinese Premier Zhu Rongji declared that China wanted to be a "responsible power" (fuzeren daguo). In late 2003, Zheng Bijian, then executive vice-president of the Party School of the CPC Central Committee, introduced the term of "peaceful rise" (heping jueqi) at the Boao Forum for Asia (Xinhua 2004). The term was accepted by the Chinese leadership (Medeiros 2004). However, as a rising power concerned about its international image, China cannot ignore the doubts and misgivings from outside such as the "China Threat" debate (Munro 1992; Yee and Storey 2002; Callahan 2005). The Chinese leadership might have recognised that the assertiveness reflected in "peaceful rise" could fuel perceptions that China was a threat to the established order dominated by the West. As a result, the concept "peaceful rise" gradually faded away in the Chinese political discourse and was replaced by the term "peaceful development" (heping fazhan). In May 2004, China's President Hu Jintao used "peaceful development" in a speech at the Boao Forum for Asia. In December 2005, The State Council Information Office (2005) of People's Republic of China issued a white paper titled China's Peaceful Development Road.

After Xi Jinping became the General Secretary of the CPC in November 2012, Beijing has become more confident in expressing its dissatisfaction at the gap between China's growing national strength and its status in the international system. In a speech at the 27 th collective study meeting of the CCP Central Politburo, President Xi stressed that China should participate in the international efforts to make the global governance system become more fair and reasonable and thereby create more favourable conditions for China's development as well as the world peace (Xinhua 2015). To that end, China has shown willingness to play a more active role in international affairs, including UN peacekeeping.

\section{China's Active Policy on UN Peacekeeping in the Twenty-First Century}

Being a rising power in the twenty-first century, China has adopted an active UN peacekeeping policy. The activeness is demonstrated not only in its strong support for UN peacekeeping operations and relevant affairs, but also in its evolving doctrine on UN peacekeeping.

As of 31 August 2017, China had 2654 peacekeepers, including 2417 troops, 81 UN Military Experts on Mission (UNMEM) and staff 
Table 13.1 China's contribution of peacekeeping personnel to ongoing UN PKOs, as of 31 March 2017

\begin{tabular}{llccccr}
\hline Operations & Host country & $\begin{array}{l}\text { Individual } \\
\text { police }\end{array}$ & $\begin{array}{l}\text { Formed } \\
\text { police unit }\end{array}$ & $\begin{array}{l}\text { UNMEM } \\
\text { \& Staff } \\
\text { officer }\end{array}$ & $\begin{array}{l}\text { Contingent } \\
\text { troop }\end{array}$ & Total \\
\hline MINURSO & West Sahara & & & 11 & & 11 \\
MINUSMA & Mali & & & 8 & 395 & 403 \\
MONUSCO & The DRC & & & 16 & 218 & 234 \\
UNAMA & Afghanistan & 1 & & & & 1 \\
UNAMID & $\begin{array}{l}\text { Darfur, } \\
\text { Sudan }\end{array}$ & & & 10 & 365 & 375 \\
UNIFIL & Lebanon & & & 8 & 410 & 418 \\
UNFICYP & Cyprus & 7 & & & & 7 \\
UNMIL & Liberia & 1 & 140 & 1 & & 142 \\
UNMISS & South Sudan & 7 & & 23 & 1029 & 1059 \\
UNTSO & Middle East & & & 4 & & 4 \\
Total & & 16 & $\mathbf{1 4 0}$ & $\mathbf{8 1}$ & $\mathbf{2 4 1 7}$ & $\mathbf{2 6 5 4}$ \\
\hline
\end{tabular}

Source Author's own calculation based on data from United Nations (2017a)

officers, and 156 police officers, in 9 of the 15 ongoing United Nations PKOs and one special political mission (see Table 13.1). ${ }^{3}$ It ranked 11th among the 124 troop and police-contributing countries and number one among the five UN Security Council permanent members (P5) in terms of the contribution of personnel (United Nations 2017b). So far China has contributed a total of more than 35,000 military and police peacekeepers to the UN-commanded PKOs and special political missions. As is shown in Chart 13.2, back in 2000, China had the lowest number of UN peacekeepers among the permanent members. However, the last 15 years, China's contribution of UN peacekeepers has increased rapidly while contributions of all the other four P5 have either remained at a low level or significantly decreased.

China's assessment rate in contribution to UN peacekeeping in the 2016-2018 fiscal years is $10.28 \%$ (United Nations 2015). As is shown in Chart 13.3, back in 2001, its assessment rate was merely about two percent. However, since then, China's assessment rate has rapidly increased

\footnotetext{
${ }^{3}$ It should be noted that uniformed personnel, including military observers, and police officers on political missions commanded by the UN Department of Political Affairs are UN peacekeepers too.
} 


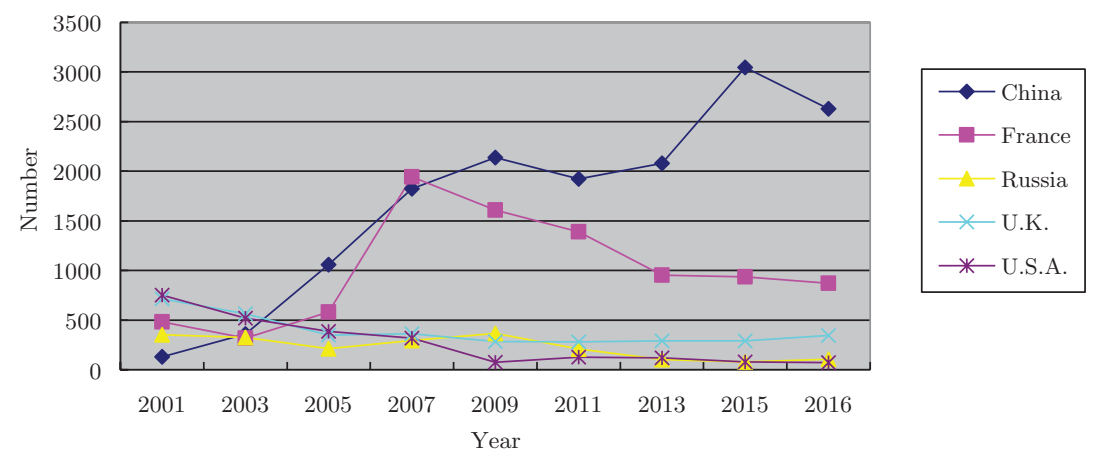

Chart 13.2 UNSC permanent members' contribution of UN Peacekeepers (2001-2016) (Source Author's own calculation based on data from United Nations 2017c)

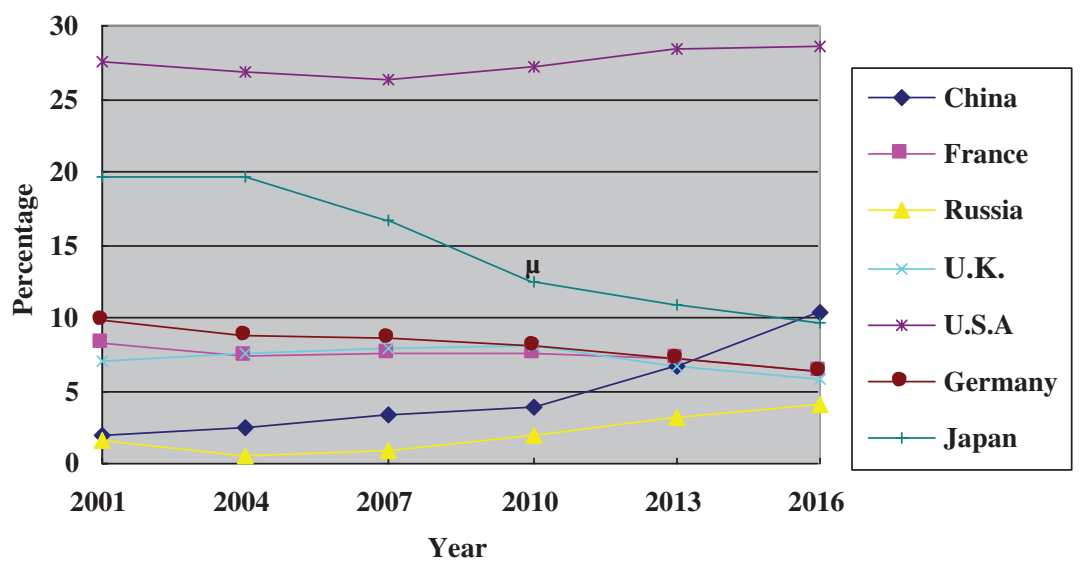

Chart 13.3 Major Power's assessment rate in contribution to UN Peacekeeping (2001-2016) (Source Author's own calculation based on data from United Nations 2015) 
while most other major power's assessment rates have declined. China is now the second largest UN peacekeeping budget contributor among all the 193 UN Member States, and the largest among the developing countries (United Nations 2015).

China also attaches great importance to peacekeeping personnel training. It has invested heavily in setting up peacekeeping training facilities and uses them, among other things, as institutions for relevant international cooperation. China established China Peacekeeping Police Training Center in 2000 and the Ministry of Defense Peacekeeping Center in 2009. Both training centres have advanced facilities, which showcases China's increased material capabilities as well as strong political will of participating in UN peacekeeping.

Since 1990s China has been to learn the field of peacekeeping. It often sends delegates to participate in training courses, academic workshops and seminars held in other UN Member States, including those held in Western states such as the United Kingdom, France, Australia, the United States as well as in Nordic countries. It has also received peacekeeping training assistance from United Kingdom, France, and other states. However, in recent years, as China gradually gained more and more experience in peacekeeping, it is no longer merely a "participant" or "learner" of various peacekeeping-related international activities, but also an increasingly active organiser. Both the Chinese police and military peacekeeping training institutions often host international training courses and academic exchange activities.

China's strong support for UN peacekeeping is also reflected in its active engagement in hotspot issues that affect international peace and security. Working together with their international colleagues including those from the United States and Europe, the Chinese special representatives and minister of foreign affairs have made significant contributions to the peace process in South Sudan, Darfur in Sudan, the eastern part of the Democratic Republic of the Congo (DRC), Mali, Afghanistan, and the Middle East. ${ }^{4}$ Besides, China has given strong support for the UNSC Resolution 1816 (UN 2008), which calls for international efforts to fight pirate activities in the Gulf of Aden. It has deployed the PLA Navy ships to conduct escort missions in the region's international waters since 2008. On 4 January 2014, one Chinese frigate Yancheng joined

\footnotetext{
${ }^{4}$ Interview with an official from the Chinese Ministry of Foreign Affairs, Beijing, 18 June 2014.
} 
the international escort mission for the disposal of Syrian chemical weapons in response to appeals from the UNSC and the Organization for the Prohibition of Chemical Weapons (Xinhua 2014a).

The PLA, China's armed forces, has included peacekeeping as one of its major missions. In March 2013, the MND issued a white paper called The Diversified Employment of China's Armed Forces, which for the first time systematically explained the PLA's missions in the twenty-first century (State Council Information Office 2013). The white paper states that the PLA has diversified its missions to include defending national sovereignty, security, and territorial integrity, supporting national economic and social development, and safeguarding world peace and regional stability. It explains that the PLA should assume its due international responsibilities, and play an active role in maintaining world peace, security, and stability (State Council Information Office 2013).

Most significantly, on 28 September 2015, in his statement at the General Debate of the 70th Session of the UN General Assembly and remarks at the UN Peacekeeping Summit, Chinese president Xi Jinping (2015a, b) announced six important commitments to support the improvement and strengthening of UN peacekeeping:

First, China will join the new UN peacekeeping Capability Readiness System and set up a permanent peacekeeping police squad and build a peacekeeping standby force of 8000 troops. Second, China will give favorable consideration to UN requests for more Chinese engineering soldiers and transportation and medical staff to take part in UN PKOs. Third, in the coming five years, China will train 2000 peacekeepers from other countries, and carry out 10 demining assistance programs which will include training and equipment provision. Fourth, in the coming five years, China will provide free military aid of US\$100 million to the African Union to support the building of the African Standby Force and the African Capacity for Immediate Response to Crisis. Fifth, China will send the first peacekeeping helicopter squad to UN PKOs in Africa. Sixth, China will establish a 10 -year, US\$1 billion China-UN peace and development fund to support the UN's work, advance multilateral cooperation and contribute more to world peace and development. Part of the fund will be used to support UN PKOs.

These six Chinese measures show that China has decided to expand its contribution to UN peacekeeping and relevant international efforts of maintaining peace and security. Considering its rising power identity as well as being a key UN Member State, China's huge support package is 
of special significance. Although during the 2015 UN Summit and afterwards, many other Member States have also made similar promises to support the UN peacekeeping, so far none of them have given support as significant as that of China.

As most of the ongoing PKOs are operating in volatile places, increasing contribution of peacekeepers can mean increasing possibilities of fatalities and injuries. On 1 June 2016, terrorists attacked the barracks of the Chinese peacekeeping security unit located in Gao, Mali with a vehicle bomb, leading to the death of one Chinese peacekeeper and four injuries. A few weeks later, on 10 July, another two Chinese peacekeepers were killed and five more injured in a mortar exchange between the government forces and the rebel army in Juba, South Sudan. Although both accidents have aroused heated discussion among the Chinese public on security of peacekeepers, Beijing has not shown any signs of withdrawing troops from Mali or South Sudan or intention to reduce its contribution of peacekeeping personnel. In October 2016, China announced that the equipment of a 140-person PLA air unit with four multifunctional helicopters was been transported to the African Union/United Nations Hybrid Operation in Darfur (UNAMID). In September 2016, a 150-person Chinese police unit passed the UN selection process to serve as the first standby Formed Police Unit in the organisation's history. By November 2017, PLA has organized a standby peacekeeping force of 19 units with 8000 troops. Apparently, a rising China is determined to be an active UN peacekeeper despite increasing fatalities and injuries of Chinese peacekeepers.

\section{China's Peacekeeping Doctrine in the Twenty-First Century}

China's new identity of a rising power in the twenty-first century also shapes its peacekeeping doctrine. An analysis of China's interpretation and practice of basic UN peacekeeping doctrine, such as the three fundamental peacekeeping principles and the concept of responsibility to protect (R2P), helps understand this country's UN peacekeeping policy.

\section{Three Fundamental Peacekeeping Principles}

UN peacekeeping has three core principles - consent, impartiality, and non-use of force-which China believes are fundamental to winning the confidence and support of Member States for peacekeeping operations 
and ensuring their smooth conduct (Chinese Ministry of Foreign Affairs 2014). Although today's China still insists that peacekeeping should adhere to these principles, it's approach to and practice of them have undergone some changes.

While insisting that the consent of a host country is a prerequisite to establishing a PKO, Beijing also agrees that sometimes consent cannot be obtained without efforts of the international community. In recent years, China has become increasingly willing to participate in those efforts. For example, it is believed to have joined the international community in persuading Sudan, South Sudan, the DRC, and Syria to accept UN peacekeeping or cooperate with the UN in recent years. ${ }^{5}$

Regarding impartiality, although China maintains this principle should be abided by in peace efforts by the international community, it does not practice the principle in a rigid way. For example, Beijing insists that the internal affairs of any state should not be interfered with by outside forces. However, it is willing to play an active role in many conflict-affected countries' peace processes through different means, including engaging with opposition parties under special circumstances.

In early June 2011, China confirmed that its ambassador to Qatar, Zhang Zhiliang, had met with the chairman of Libya's National Transitional Council, Mustafa Abdel Jalil (Xinhua 2011). One retired Chinese diplomat noted that China's engagement with the Libyan opposition leader before the fall of Gaddafi's government showed flexibility in its principle of non-intervention. ${ }^{6}$ The special representative of the Chinese government on African affairs has had talks with South Sudan's conflicting parties since 2012.7 On 5 February 2013, the Chinese ambassador to Egypt, Song Aiguo, met with Syrian National Coalition for Opposition and Revolutionary Forces chairman Ahmed Moaz Al-khatib in Cairo (Xinhua 2013). Chinese Foreign Ministry spokesperson Hua Chunying noted during a press conference: "What is the core is that we should push both sides in Syria to blaze a 'middle

\footnotetext{
${ }^{5}$ Interview with a Chinese diplomat, Beijing, 18 June 2014.

${ }^{6}$ Interview with a Chinese retired diplomat, Langfang, China, 25 May 2016.

${ }^{7}$ Interview with a Chinese retired diplomat, Beijing, 12 June 2014.
} 
way' by keeping in mind Syria's national conditions and the interests of all parties" (Xinhua 2014b). When asked to confirm the report about an Afghan Taliban delegation's visit to Beijing in late November 2014, another Chinese foreign spokesperson, Hong Lei, said:

As a friendly neighbor of Afghanistan, China attaches great importance to developing relations with Afghanistan, hopes to see Afghanistan achieve lasting peace, stability and development at an early date, supports the 'Afghanowned' process towards peace and reconciliation and wishes to play a constructive role to that end. (Chinese Ministry of Foreign Affairs 2015)

China maintains that peaceful settlement of international disputes and non-use of force in international relations is an important principle of the UN Charter and a basic norm of international law (Chinese Ministry of Foreign Affairs 2005). Nevertheless, Beijing does not rule out the necessity of using force under exceptional circumstances. When use of force is necessary, Beijing insists that use of force should meet two basic requirements: "one is the authorization of the UNSC, the other for the purpose of self-defense or defense of the mandate" (Chinese Ministry of Foreign Affairs 2005).

China's changing attitude towards the principle of use of force is well reflected in its contribution of security troops to PKOs in recent years. The international community has long expected China to contribute “combat troops" to PKOs (International Crisis Group 2009; Gill and Huang 2009). Since the early 1990s, China had for a long period of time refrained from contributing security troops to PKOs. However, this stance has gradually changed in the twenty-first century. In 2004, China deployed a 125-person peacekeeping Formed Police Unit to the United Nations Stabilization Mission in Haiti (MINUSTAH). In December 2013, China for the first time deployed a security company to a PKO, the United Nations Multidimensional Integrated Stabilization Mission in Mali (MINUSMA). More significantly, in 2015 China deployed a 700-person infantry battalion to the UN Mission in South Sudan (UNMISS) (Xinhua 2014c). In the new millennium, although China still has concerns regarding the use of force, it no longer minds being directly engaged in use of force in UN-commanded PKOs when there is UNSC authorisation and the situation on the ground deems it necessary to use force. 


\section{$R 2 P$}

Entering the twenty-first century, the post-Westphalian interventionist concept of responsibility to protect (R2P) has begun to challenge Westphalian norms of sovereignty and non-intervention. Although Beijing has in principle endorsed R2P by supporting the 2005 World Summit Outcome, it has never embraced the interventionism embodied in the concept. According to the 2005 World Summit Outcome, R2P has three pillars:

Pillar One: Each individual state has a responsibility to protect its population from mass atrocities.

Pillar Two: The international community has a responsibility to assist the state to protect its population.

Pillar Three: If the state fails to protect its citizens from mass atrocities and peaceful measures have failed, the international community has the responsibility to intervene through coercive measures. But military intervention is the last resort (UN 2005).

China insists that most of the weight of R2P should fall on Pillar One. It is concerned that R2P may serve as a sharp tool for the West, which prefers Pillars Two and Three, to skip the consent of host countries and penetrate the wall of traditional sovereignty (He 2014a). On 24 July 2009, the Chinese ambassador to the UN, Liu Zhenmin, made a statement at the plenary session of the General Assembly on the question of $\mathrm{R} 2 \mathrm{P}$, insisting that

The government of a given state bears the primary responsibility for protecting its citizens. The international community can provide assistance, but the protection of the citizens ultimately depends on the government of the state concerned...there must not be any wavering over the principles of respecting state sovereignty and non-interference of internal affairs....it is necessary to prevent 'R2P' from becoming another version of 'humanitarian intervention. (Permanent Mission of the People's Republic of China to the UN 2009)

According to one retired Chinese diplomat, the government largely regards $\mathrm{R} 2 \mathrm{P}$ as a concept or a good wish, which solely has significance as political morality. ${ }^{8}$ Nevertheless, China has not adopted a rigid policy

\footnotetext{
${ }^{8}$ Interview with a Chinese retired diplomat, Langfang, China, 13 December 2012.
} 
on $\mathrm{R} 2 \mathrm{P}$ that would rule out international intervention under special circumstances. It does recognise that the concept of R2P can apply to the four international crimes of "genocide, war crime, ethnic cleansing, and crimes against humanity" (Permanent Mission of the People's Republic of China to the UN 2009).

One major concern of the supporters of R2P is with the concept of protection of civilians (PoC). As is shown in China's support for the UN guiding principles on the use of force, which makes it clear that force can be used only as a last resort in implementing UNSC authorisation, China basically agrees to the concept PoC. Chinese peacekeepers in places like Mali and South Sudan are carrying on PoC tasks according to their mission mandates.

In recent years, the Chinese academic community is becoming increasingly interested in discussing R2P. In 2012, Ruan Zongze, a senior researcher at the China Institute of International Studies (CIIS), a top Chinese think tank affiliated to the Chinese Ministry of Foreign Affairs (MFA), coined the concept of responsible protection (RP) vis-ávis R2P (Ruan 2012a). RP has six elements:

1. Any intervention should protect innocent civilians in the country concerned as well as regional peace and stability, rather than specific political factions or armed forces;

2. The UN Security Council is the only body with the legitimacy to implement "humanitarian intervention";

3. The necessary precondition for the implementation of force must be that all diplomatic and political means of settlement have been exhausted;

4. The goal of protection should be to prevent or alleviate a humanitarian disaster, rather than the overthrow of a government;

5. National reconstruction after intervention and protection should be given sustained support;

6. The UN should establish a monitoring mechanism, and an effective evaluation and accountability system (Ruan 2012b).

Although the concept of RP has not been officially endorsed by the Chinese Government, it has attracted great international attention. As the six elements of RP are basically in line with China's official discourse regarding $\mathrm{R} 2 \mathrm{P}$, some international academics regard $\mathrm{RP}$ as expressing the Chinese protection approach in relation to R2P (Evans 2014; Thakur 2013). 
$\mathrm{RP}$ was coined and discussed under the background that a rising China seeks to be an international norm contributor. Since 2014, the Chinese leadership has begun to introduce a concept called "Chinese Approach" (zhongguo fangan), which advocates that China has both the capabilities and willingness to help improve global governance by providing solutions with Chinese characteristics.

Some Chinese academics have also done research in China's normative contribution to UN peacebuilding. For example, since the beginning of the new century, many Western academics have criticised "liberal peace," the paradigm of international peacebuilding efforts. Liberal peace as a peacebuilding norm has two pillars, one is Western liberal democracy-oriented institution building, and the other liberal market economy. Critics point out that liberal peace-dominated peacebuilding has created "virtual peace" in many post-conflict states (Paris 2004; Richmond 2006; Taylor 2007; Richmond and Franks 2009; Mac Ginty and Richmond 2009; Mac Ginty 2010; Salih 2010; Campbell et al. 2011). He Yin coined "developmental peace", claiming that both China's peaceful rise as well as its international aid practice demonstrates a peace norm significantly different from liberal peace. Developmental peace advocates political and social stability supported by strong institutions and an economic development-oriented national development strategy. Liberal peace and developmental peace are two peace norms differing widely in their ways and contents. One seems to be a contrast to the other, competing for attention and resources in peacebuilding as well as legitimacy in international norm system. However, a comparison study of the peacebuilding practice in Haiti and Liberia shows that when the two peace norms are promoted at the same time, they can not only co-exist peacefully, but also improve the effect of peacebuilding efforts (He 2014b).

Both RP and developmental peace are coined by Chinese academics, which symbolises a turn of China's attitude towards international norms, from passive acceptance or rigid rejection in the past to today's increasingly active participation in debate. Being a rising power in the twenty-first century, China "increasingly sees itself as a norm-shaper and norm-maker with the international system" (Garwood-Gowers 2016; He 2014b).

\section{Conclusion}

Since China's return to the UN, great changes have taken place to the country's national identity, from a semi-revolutionary state in the 1970s and an integrated member of the international community in 
the 1980s and 1990s, to a rising power in the twenty-first century. The country's policy on UN peacekeeping has changed accordingly, from opposition in the 1970s to gradually expanded reactive participation in the 1980s and 1990s, to increasingly active participation in the twenty-first century. China's new identity of a rising power in the twenty-first century also shapes its doctrine on peacekeeping. It can show certain degree of flexibility or be creative in practicing the three fundamental principles of peacekeeping and the concept of R2P in order to play a constructive role in UN peacekeeping affairs, especially when the authority of the United Nations Security Council (UNSC) can be secured or when Beijing considers the specific circumstances to be exceptional.

As a rising power as well as one of the P5, China's support for UN peacekeeping benefits not only the country's peaceful rise strategy, but also the UN peacekeeping efforts and global security governance. However, although the UN and international community have reasons for applauding China's active policy on UN peacekeeping, some challenges should not be ignored. The first and foremost of these challenges is about China's role in the UN peacekeeping regime in the new millennium. Today's China is the second largest UN peacekeeping budget contributor among all UN Member States and the most active UN peacekeeper among the P5. However, research shows that China's discursive power in the UN peacekeeping affairs is in great deficit when compared to that of other major powers (He 2016). As a veto-wielding Member State in the UNSC, China has big influence in the high politics of UN peacekeeping affairs. However, when it comes to the bureaucratic or operational level, China is lagging behind many other major powers, including some non-P5 Member States. For example, China only ranks number 14 among all the 193 Member States in terms of number of civilian employees in the UN Secretariat (He 2016). Moreover, there are only 11 Chinese nationals occupying Dl or above level posts in the UN Secretariat, whereas the numbers of the United States, United Kingdom, and France are 50, 24 and 17 respectively (He 2016). China is also under-represented in all kinds of policy consultation activities initiated by the UN (Prodi 2014). For example, since 2000, the UN has nominated six important expert panels to review and advise on UN peacekeeping affairs. China has only been invited to participate in two of them (He 2016). Back in 2000, there was no Chinese representative in the Panel on the United Nations 
Peace Operations (United Nations 2000). In 2015, China was almost once again excluded from the High Independent Panel for United Nations Peace Operations (HIPPO). ${ }^{9}$

Being a rising power as well as an active supporter for UN peacekeeping, China will never be satisfied at being regarded as merely a peacekeeping personnel and budget contributor. Through actively supporting UN peacekeeping, China wishes to share with the rest of the world its material success, but also intellectual achievement accumulated in its peaceful rising, including as they relate governance. China is ready to contribute with a "Chinese Approach" to global governance, including UN peacekeeping. To further this establish China's role in the international peacekeeping regime, two questions ought to be asked, researched, and finally tackled: How to improve China's representation in the UN peacekeeping regime so that more Chinese experts can participate in advising, designing, and running PKOs? And, how to welcome China's enthusiasm for UN peacekeeping and find it a comfortable position in the UN peacekeeping regime, which is undergoing critical reform and transformation?

\section{REFERENCES}

Callahan, William A. 2005. How to Understand China: The Dangers and Opportunities of Being a Rising Power. Review of International Studies 31: 701-714.

Campbell, Susanna, David Chandler, and Meera Sabaratnam. 2011. A Liberal Peace? The Problems and Practices of Peacebuilding. London: Zed Books.

Chinese Ministry of Foreign Affairs. 2005. Position Paper of the People's Republic of China on the United Nations Reform, June 7. Beijing.

Chinese Ministry of Foreign Affairs. 2014. Foreign Ministry Spokesperson Hong Lei's Remarks on the UN Security Council's Vote on the Draft Resolution to Refer the Situation in Syria to the International Criminal Court, May 23. Beijing.

Chinese Ministry of Foreign Affairs. 2015. Foreign Ministry Spokesperson Hong Lei's Regular Press Conference, January 14. Beijing.

Choedon, Yeshi. 2005. China's Stand on UN Peacekeeping Operations: Changing Priorities of Foreign Policy. China Report 41 (1): 39-57.

\footnotetext{
${ }^{9}$ Interview with a Chinese diplomat at the Chinese Ministry of Foreign Affairs, Beijing, 2016.
} 
Evans, Gareth. 2014. The Consequence of Syria: Does the Responsibility to Protect Have a Future? In E-International Relations, Edited CollectionR2P, Syria and Humanitarianism in Crisis. www.e-ir.info/2014/01/27/ the-consequence-of-non-intervention-in-syria-does-the-responsibility-to-protect-have-future. Accessed 26 Apr 2017.

Finnemore, Martha. 1996. National Interests in International Society. New York: Cornell University Press.

Fung, Courtney J. 2016. What Explains China's Deployment to UN Peacekeeping Operations. International Relations of the Asia-Pacific 16: 409-441.

Garwood-Gowers, Andrew. 2016. China's "Responsible Protection” Concept: Reinterpreting the Responsibility to Protect (R2P) and Military Intervention for Humanitarian Purposes. Asian Journal of International Law 6 (1): 89-118.

Gill, Bates, and Chin-hao Huang. 2009. China's Expanding Role in Peacekeeping: Prospects and Policy Implications. SIPRI Policy Paper 25, Stockholm International Peace Research Institute, Stockholm.

He, Yin. 2007. China's Changing Policy on UN Peacekeeping Operations. Asia Paper, Institute for Security and Development Policy, Stockholm.

He, Yin. 2014a. China-EU Cooperation on UN Peacekeeping: Opportunities and Challenges. In Europe and China in 21st Century Global Politics: Partnership, Competition, or Co-evolution? ed. Frauke Austermann, Xiaoguang Wang, and Anastas Vangeli, 43-61. London: Cambridge Scholars.

$\mathrm{He}$, Yin. 2014b. Norms Competition and Complementation: Peacebuilding as Case Study. World Economics and Politics 4: 105-121.

He, Yin. 2016. UN Peacekeeping Affairs and China's Discursive Power. World Economics and Politics 11: 41-62.

Ikenberry, John. 2008. The Rise of China and the Future of the West: Can the Liberal System Survive. Foreign Affairs 87 (1): 23-37.

International Crisis Group. 2009. China's Growing Role in UN Peacekeeping. Asia Report No. 166. International Crisis Group, Beijing, New York and Brussels.

Johnston, Alastair I. 2008. Social State: China in International Institutions, 1980-2000. Princeton: Princeton University Press.

Kim, Ilpyong. 1987. The Strategic Triangle: China, the United States \& the Soviet Union. Saint Paul: Paragon House.

Kratochwill, Friedrich. 1989. Rules, Norms, and Decision: On the Conditions of Practical and Legal Reasoning in International Relations and Domestic Affairs. London: Cambridge University Press.

Lanteigne, Marc. 2014. China's Peacekeeping Policies in Mali: New Security Thinking or Balancing Europe? MFC Working Paper No. 11, MFG Research Group, Berlin. 
Lynch, Colum. 2014. UN Peacekeepers to Protect China's Oil Interests in South Sudan. Foreign Policy, June 16.

Mac Ginty, Roger, and Oliver P. Richmond. 2009. The Liberal Peace and PostWar Reconstruction: Myth or Reality? London: Routledge.

Mac Ginty, Roger. 2010. Hybrid Peace: The Interaction Between Top-Down and Bottom-Up Peace. Security Dialogue 14 (4): 391-412.

Medeiros, Evan S. 2014. China Debates Its "Peaceful Rise" Strategy. Yale Global, June 22. https://yaleglobal.yale.edu/content/china-debates-itspeaceful-rise-strategy. Accessed 20 Apr 2017.

Munro, Ross H. 1992. Awakening Dragon: The Real Danger in Asia Is from China. Policy Review 62: 10-16.

Paris, Roland. 2004. At War's End: Building Peace After Civil Conflict. Cambridge: Cambridge University Press.

Permanent Mission of the People's Republic of China to the UN. 2009. Statement by Ambassador Liu Zhenmin at the Plenary Session of the General Assembly on the Question of Responsibility to Protect, July 24. New York.

Prodi, Romano. 2014. Forword. In China's and Italy's Participation in Peacekeeping Operations, ed. Andrea de Guttry, Emanuele Sommario, and Li-Jiang Zhu, xiv-xvii. Lanham: Lexington Books.

Qin, Yaqing. 2005. National Identity, Strategic Culture and Security Interests: On Three Hypotheses of the Relations Between China and International Society. World Economics and Politics 1: 10-15.

Richmond, Oliver P. 2006. The Transformation of Peace. Basingstoke: Palgrave Macmillan.

Richmond, Oliver P., and Jason Franks. 2009. Liberal Peace Transitions: Between Statebuilding and Peacebuilding. Edinburgh: Edinburgh University Press.

Ruan, Zongze. 2012a. Responsible Protection. China Daily, March 13.

Ruan, Zongze. 2012b. Responsible Protection: Building a Safer World. Beijing: China Institute of International Studies.

Ruggie, John Gerard. 1998. Constructing World Polity: Essays on International Institutionalisation. London: Routledge.

Salih, Mohamed. 2010. A Critique of the Political Economy of the Liberal Peace: Elements of an African Experience. In New Perspectives on Liberal Peacebuilding, ed. Edward Newman, Roland Paris, and Oliver P. Richmond, 133-158. Tokyo and New York: United Nations University Press.

Sicurelli, Daniela. 2010. Competing Models of Peacekeeping: The Role of the EU and China in Africa. Paper prepared for the Fifth Pan-European Conference on EU Politics. Porto, June 23-26. http://citeseerx.ist.psu.edu/ viedoc/download?doi=10.1.462.9906\&rep=repl\&type=pdf. Accessed 26 Apr 2017.

Stahle, Stefan. 2008. China's Shifting Attitude Towards United Nations Peacekeeping Operations. The China Quarterly 195: 631-655. 
State Council Information Office. 2005. China's Peaceful Development Road. http://en.people.cn/200512/22/eng20051222_230059.html. Accessed 20 Apr 2017.

State Council Information Office. 2013. The Diversified Employment of China's Armed Forces. www.china.org.cn/government/whitepaper/node_7181425. htm. Accessed 20 Apr 2017.

Taylor, Ian. 2007. What Fit for the Liberal Peace in Africa? Global Society 21 (4): 553-566.

Thakur, Ramesh. 2013. A Chinese Version of 'Responsible Protection.' Japan Times, November 1.

United Nations. 2000. Report of the Panel on United Nations Peace Operations. New York: United Nations.

United Nations. 2005. 2005 World Summit Outcome. New York: United Nations General Assembly.

United Nations. 2008. United Nations Security Council Resolution 1816. New York: United Nations.

United Nations. 2015. Implementation of General Assembly Resolutions 55/235 and 55/236: Report of the Secretary-General: Addendum 1. New York: United Nations.

United Nations. 2017a. UN Mission's Summary Detailed By Country, August 31. http://www.un.org/en/peacekeeping/contributors/2017/aug17_3.pdf. Accessed 22 Oct 2017.

United Nations. 2017b. Ranking of Military and Police Contributions to UN Operations, August 31. http://www.un.org/en/peacekeeping/contributors/2017/aug17_2.pdf. Accessed 22 Oct 2017.

United Nations. 2017c. Troop and Police Contributors Archive (1990-2016). http://www.un.org/en/peacekeeping/resources/statistics/contributors_ archive.shtml. Accessed 20 Apr 2017.

United Nations Statistics Division. 2016. GDP and Its Breakdown at Current Prices in US Dollars (all countries for all years). http://unstats.un.org/unsd/ snaama/dnlList.asp. Accessed 20 Apr 2017.

Wendt, Alexander. 1999. Social Theory of International Politics. Cambridge: Cambridge University Press.

Xi, Jinping. 2015a. China Is Here for Peace. Remarks by H.E. Xi Jinping of the People's Republic of China at the United Nations Peacekeeping Summit, September 28. New York.

$\mathrm{Xi}$, Jinping. 2015b. Working Together to Forge a New Partnership of WinWin Cooperation and Create a Community of Shared Future for Mankind. Statement at the General Debate of the 70th Session of the UN General Assembly, September 28. New York.

Xinhua. 2004. Peaceful Rise: Strategic Choice for China. Xinhua News Agency, April 25. 
Xinhua. 2011. China Ready to Receive Libya Opposition NTC Envoys: Diplomat. Xinhua News Agency, June 9.

Xinhua. 2013. Chinese Ambassador Meets Syrian Opposition Leader in Cairo. Xinhua News Agency, February 6.

Xinhua. 2014a. Chinese Frigate Starts Escort Mission for Chemical Weapons: FM. Xinhua News Agency, January 8.

Xinhua. 2014b. China Backs UN Syria Mediation. Xinhua News Agency, June 23.

Xinhua. 2014c. China to Send 700 Peacekeepers to South Sudan for UN Mission: Defense Ministry. Xinhua News Agency, September 25.

Xinhua. 2015. Xi Jinping: Stresses Urgency of Reforming Global Governance. Xinhua News Agency, October 13.

Yee, Herbert, and Ian Storey. 2002. The China Threat: Perceptions, Myths and Reality. London: Routledge.

Open Access This chapter is licensed under the terms of the Creative Commons Attribution 4.0 International License (http://creativecommons.org/licenses/ by $/ 4.0 /)$, which permits use, sharing, adaptation, distribution and reproduction in any medium or format, as long as you give appropriate credit to the original author(s) and the source, provide a link to the Creative Commons license and indicate if changes were made.

The images or other third party material in this chapter are included in the chapter's Creative Commons license, unless indicated otherwise in a credit line to the material. If material is not included in the chapter's Creative Commons license and your intended use is not permitted by statutory regulation or exceeds the permitted use, you will need to obtain permission directly from the copyright holder.

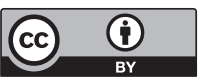

